doi: $10.15407 /$ ukrbotj73.01.084

O.Yu. AKULOV 1 , V.P. HAYOVA ${ }^{2}$

${ }^{1}$ V.N. Karazin National University of Kharkiv

4, Svobody Sq., Kharkiv, 61077, Ukraine

alex_fungi@yahoo.com

${ }^{2}$ M.G. Kholodny Institute of Botany, National Academy of Sciences of Ukraine

2, Tereshchenkivska Str., Kyiv, 01004, Ukraine

v.hayova@gmail.com

\title{
IMMOTTHIA ATROGRANA (DACAMPIACEAE, ASCOMYCOTA), A NEW FOR UKRAINE FUNGICOLOUS FUNGUS FROM THE CARPATHIANS
}

\begin{abstract}
Akulov O.Yu., Hayova V.P. Immotthia atrograna (Dacampiaceae, Ascomycota), a new for Ukraine fungicolous fungus from the Carpathians. Ukr. Bot. J., 2016, 73(1): 84-89.

Abstract. The paper reports first records of new for Ukraine genus and species of fungicolous fungi, Immotthia atrograna (Cooke \& Ellis) M.E. Barr. All collections were made in old-growth forests within protected areas in the Ukrainian Carpathians during recent mycological surveys. The fungus was found to be associated with two xylariaceous species, Annulohypoxylon cohaerens (Pers.) Y.M. Ju, J.D. Rogers \& H.M. Hsieh and A. multiforme (Fr.) Y.M. Ju, J.D. Rogers et H.M. Hsieh. Diagnostic description, nomenclature data, geographical distribution and original illustrations for both sexual and asexual morphs of the reported species are provided. Morphologically similar fungicolous fungi are briefly reviewed and compared.
\end{abstract}

Key words: Pleosporales, Immotthia, Hypoxylon, Coniothyrium parasitans, mycoparasite, Ukrainian Carpathians

Immotthia M.E. Barr is a small genus currently classified in the family Dacampiaceae (Pleosporales, Dothideomycetes, Ascomycota). The Dacampiaceae, originally named as 'Dacampieae', at present comprises 20 genera. Of them, twelve are lichenicolous, seven contain saprobes growing on plant litter or nonspecialized plant pathogens, and a single one, Immotthia, is exclusively fungicolous genus (Barr, 1987b; Dictionary of the Fungi, 2011; MycoBank, 2015). In 2002, M. Barr transferred the non-lichenicolous genera to the Teichosporaceae M.E. Barr; however, this familial placement has not been largely accepted.

Originally, M. Barr (1987a) established a new genus Immotthia to accommodate a single species, Immotthia hypoxylon (Ellis \& Everh.) M.E. Barr (basyonym Amphisphaeria hypoxylon Ellis et Everh., $\equiv$ Otthia hypoxylon (Ellis \& Everh.) Ellis \& Everh.). This monotypic genus was characterized by rather small globose to obpyriform ascomata, usually gregarious on hypostroma, long-stalked bitunicate asci, and fusoid pigmented one-septate ascospores, uniseriately arranged in the asci. The genus name means «not at all Otthia» reflecting morphological distinctness from the genus Otthia Nitschke ex Fuckel, where the type species has been previously placed. The species epithet derives from association of the fungus with stromata of Hypoxylon spp. hosts.

(C) O.Yu. AKULOV, V.P. HAYOVA, 2016
Later, after examination of the holotype specimen of Sphaeria atrograna Cooke \& Ellis, M. Barr (1993) proposed a new combination in the genus Immotthia, I. atrograna (Cooke \& Ellis) M.E. Barr. At the same time, she pointed out that the studied collection morphologically was not different from Immotthia hypoxylon, thus the species were considered as synonyms. The synonymy was confirmed in further studies of type material by W. Jaklitsch et al. (2002). Of the two basyonyms, Sphaeria atrograna was described seven years earlier than Amphisphaeria hypoxylon, therefore the priority name of the fungus is Immotthia atrograna.

In 2002, M. Barr published a new combination, Immotthia atroseptata (Piroz.) M.E. Barr, based on Didymosphaeria atroseptata Piroz. parasitizing apothecia of Pestalopezia rhododendri Seaver on fallen leaves of Rhododendron maximum L. Described from USA, this fungus is known exclusively from the holotype specimen (Grand, 1973; Pirozynski, 1973; Barr, 2002).

One more morphologically similar yet undescribed species, repeatedly collected in several countries of Western Europe (Denmark, France, Luxembourg), is believed to belong to the genus Immotthia. This parasitic fungus was found in all localities on apothecia of another discomycete, Velutarina rufo-olivacea (Alb. \& Schwein.) Korf (AscoFrance, 2015). 
Thus, all known up to now species of the Immotthia genus are apparently obligate fungicolous fungi. The genus is not different in ecological preferences from other fungicolous genera, such as Hypomyces (Fr.) Tul. \& C. Tul. or Cosmospora Rabenh., although is represented by much lower number of species.

In Ukraine, none of the Immotthia species has been registered so far. Several specimens recently collected by the authors, independently in different localities in the Ukrainian Carpathians, were subsequently identified as Immotthia atrograna. Since both genus and species are newly recorded in Ukraine, we provide below nomenclature data, diagnostic description, original illustrations, geographical distribution and other related information for the reported fungus. The specimens are deposited in Herbarium of the Department of Mycology and Immunology, V.N. Karazin National University of Kharkiv ( $C W U \mathrm{Myc}$ ) and in Mycological Herbarium of M.G. Kholodny Institute of Botany, National Academy of Sciences of Ukraine $(K W)$.

Immotthia atrograna (Cooke \& Ellis) M.E. Barr, Mycotaxon 46: 71, 1993 (Fig, 1-3)

Syn.: Sphaeria atrograna Cooke \& Ellis, Grevillea 8(45): 15, 1879; $\equiv$ Amphisphaeria atrograna (Cooke \& Ellis) Sacc., Syll. Fung. 1: 722, 1882; 三 Gibbera atrograna Trans. Brit. Mycol. Soc. 65(3): 396, 1975; $\equiv$ Melamomma atrogranum (Cooke \& Ellis) Cooke, Grevillea, 16: 52, 1887; = Amphisphaeria deformis [deformata] Ellis \& Langl., J. Mycol. 4(12): 123, 1888; = Amphisphaeria pilosella Ellis \& Everh., Proc. Acad. nat. Sci. Philad. 47: 418, 1895; 三 Gibbera pilosella (Ellis \& Everh.) Sivan., Trans. Brit. Mycol. Soc. 65(3): 395, 1975; = Amphisphaeria confertissima Ellis \& Everh., Proc. Acad. nat. Sci. Philad. 47: 418, 1895; E Gibbera confertissima (Ellis \& Everh.) Sivan., Trans. Brit. Mycol. Soc. 65(3): 395, 1975; = Immotthia hypoxylon (Ellis \& Everh.) M.E. Barr, Mycotaxon 29: 504, 1987; $\equiv$ Amphisphaeria hypoxylon Ellis \& Everh., J. Mycol. 2(4): 41, 1886; 三 Otthia hypoxylon (Ellis \& Everh.) Ellis et Everh., 1892; $\equiv$ Dimerium hypoxylon (Ellis \& Everh.) Petr., Sydowia 11: 338, 1958; इ Melamomma hypoxylon (Cooke \& Ellis) Cooke, Grevillea, 16: 53, 1887; ?= Neopeckia episphaeria Höhn., Ann. Mycol. 17(2-6): 120, 1920; ?= Sphaeria insidens Schwein., Schr. naturf. Ges. Leipzig 1: 39, 1822; 三 Myrmaecium insidens (Schwein.) Sacc., Syll. Fung. 1: 601, 1882; $\equiv$ Anthostoma insidens (Schwein.) Berl. \& Voglino, Syll. Fung. Add. Vol. I-IV: 47, 1886; 三 Hypoxylon insidens (Schwein.) Ellis \& Everh., N. Amer. Pyren. (Newfield):
653, 1892; ?= Jahnula parasitica Kirschst. ined. Petrak, 1958.

Anamorph: Coniothyrium parasitans (Berk. \& Ravenel) Tassi, Bulletin Labor. Orto Bot. de R. Univ. Siena 5: 25, 1902; $\equiv$ Sphaeropsis parasitans Berk. \& Ravenel, Grevillea 2(24): 180, 1859; 三 Macroplodia parasitans (Berk. \& Ravenel) Kuntze, Revis. gen. pl. (Leipzig) 3: 492, 1898; 三 Cicinnobella parasitans (Berk. \& Ravenel) Petr., Sydowia 11: 338, 1958.

Icon.: Chlebicki, Acta Mycologica, 2005, 40(1): 76, fig. 1D (as Immotthia hypoxylon); Jaklitsch et al., Österreichische Zeitschrift für Pilzkunde, 2002, 11(14): 103, figs. 9-12; Barr, Prodromus..., 1987, p. 101, Pl. 23 Q; Barr, Mycotaxon, 2002, 82(3): 379: figs. q-s; Barr, Mycotaxon, 1993, 46(1): 69, figs. p-r; Sivanesan, Trans. Brit. Mycol. Soc., 1975, 65(3): 396, fig. 1A, Pl. 50(8).

Hypostroma appearing as a dark brown to black crust under pseudothecia on the surface of host stromata, 50$300 \mu \mathrm{m}$ wide, in section composed of dark brown textura angularis made up of thick-walled $(0.5-1.5 \mu \mathrm{m})$ cells, $6-11 \mu \mathrm{m}$ in diameter, similar to cells of ascomatal wall in surface view. Ascomata (pseudothecia) superficial on hypostroma, numerous, usually gregarious to densely aggregated, globose, obpyriform, often becoming laterally compressed by mutual pressure, 120-270 (up to 385$) \mu \mathrm{m}$ in diameter, black, carbonaceous, surface glabrous to roughened by protruding cells. Ostioles pallid to reddish-brown, inconspicuous, $30-50 \mu \mathrm{m}$ in diameter, appearing as a circular pore in apical part of ascomata, occasionally slightly papillate. Interior of the ostiolar canal is lined with short hyaline to pale brown periphyses, broadly rounded at the apex, $8-18 \times 2-3 \mu \mathrm{m}$. Peridium three-layered, 30-50 $\mu \mathrm{m}$ wide, equally thick or slightly thicker toward the ascomatal apex. External layer 10-15 $\mu \mathrm{m}$ wide, composed of dark angular cells resembling those of hypostroma. Middle layer 6-15 $\mu \mathrm{m}$ thick, consists of 2-4 layers of more loosely arranged and lighter coloured cells. Internal layer $10-20 \mu \mathrm{m}$ in width, of pale to subhyaline cells $3-8 \mu \mathrm{m}$ in diameter. In addition, at the base of ascomata, between the internal layer and hymenium, a sterile tissue up to $80 \mu \mathrm{m}$ high is frequently formed. The outer surface of peridium smooth to verruculose, covered by protruding cells of the external layer of pseudothecia. Hamathecium composed of numerous pseudoparaphyses, hyaline, filiform, cellular, branching, easily detached from peridium, exceeding asci in length, 1.5-3.0 $\mu \mathrm{m}$ wide. Asci bitunicate, oblong cylindrical, thick-walled (up to $3 \mu \mathrm{m}$ thick at the apex), formed in a broad basal fascicle, (4-6-)8-spored, $(50-) 60-90 \times(5-) 6-10$ 


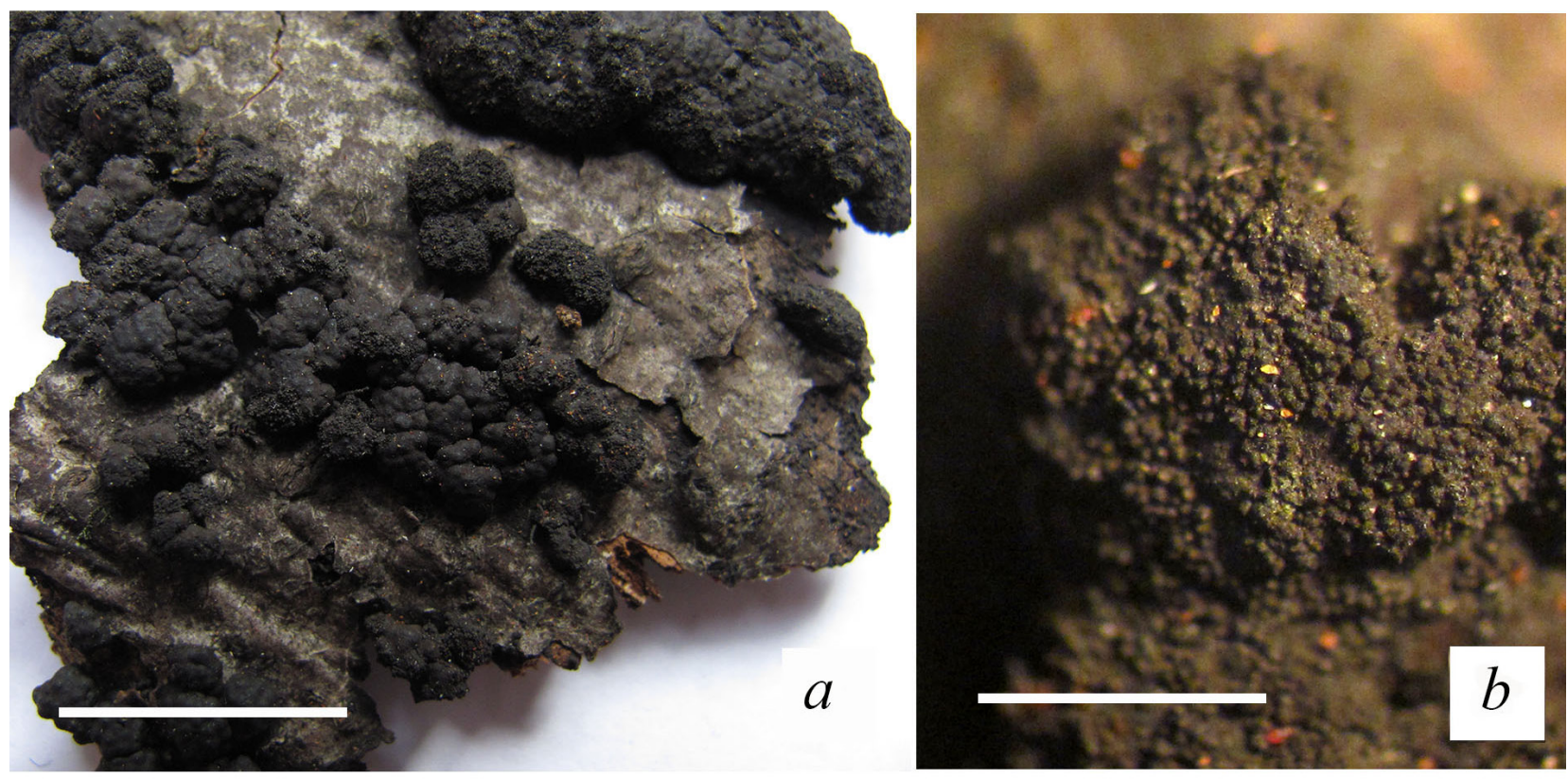

Fig. 1. Immotthia atrograna [CWU Myc AS 4704]: $a$ - habit on stromata of Annulohypoxylon cohaerens, bar: $2 \mathrm{~cm} ; b-$ general view of ascomata and conidiomata, bar: $500 \mu \mathrm{m}$

$\mu \mathrm{m}$; ascospores arranged within the asci in obliquely uniseriate manner. Ascospores yellow-brown to reddish-brown, ellipsoid, obovoid to biconical, slightly asymmetric, inaequilateral, one-septate, constricted at septum, $(8-) 9-14(-18) \times(4.5-) 5-6(-7) \mu \mathrm{m}$; septum central to eccentric, about $1 \mu \mathrm{m}$ in width, slightly darker than spore walls; upper cell longer and wider than lower one, ends subacutely rounded, 1-3 guttules per cell; walls smooth to verruculose, surrounded by a hyaline perispore, non-dehiscent in $\mathrm{KOH}$.

Anamorph pycnidial; in external appearance and general shape conidiomata remarkably similar to ascomata, sometimes differ in slightly smaller size. Conidiophores absent. Conidiogenous cells enteroblastic, hyaline, smooth, discrete, determinate, irregularly ampulliform or doliiform, (8-)10(-14) $\times 5(-7) \mu \mathrm{m}$, proliferating as typical phialides, with minute colarette and conspicuous periclinal thickening. Conidia ellipsoid, rounded at both ends or slightly tapering toward one end, one-celled, at first hyaline, later light- to medium-brown, 6-8(-9) $\times 3-5 \mu \mathrm{m}$, smooth or finely verruculous, usually bi-guttulate*

* A few collections from USA, quite closely resembling Immotthia atrograna, differ in having smaller ascospores and conidia. For example, a specimen from North Carolina at BPI with ascospores $6-8(-9) \times 2-3 \mu \mathrm{m}$ and conidia $4-5 \times 1 \mu \mathrm{m}$ has unclear taxonomic position (Barr, 1993).
Specimens examined. On stromata of Annulohypoxylon cohaerens (Pers.) Y.M. Ju, J.D. Rogers \& H.M. Hsieh on wood of Fagus syvlatica L. - Chernivtsi Region, Vyzhnytsia District, Vyzhnytsia National Nature Park, fir-beech forest, $48^{\circ} 12^{\prime} \mathrm{N} 25^{\circ} 12^{\prime} \mathrm{E}, 22.08 .2015$, V.P. Hayova [ $K W$ 60674]. - Ivano-Frankivsk Region, Nadvirna District, Gorgany Nature Reserve, Gorgany forestry, spruce-beech forest, quarter $14,48^{\circ} 29^{\prime} \mathrm{N} 24^{\circ}$ $17^{\prime} \mathrm{E}, 29.08 .2010$, V.P. Hayova [ $C W U$ (Myc) AS 5803, $=K W 60665] .-$ Lviv Region, Skole District, Skolivski Beskidy National Nature Park, old-growth beech forest on the slope of Mount Parashka (protected area), $49^{\circ}$ $04^{\prime} 04^{\prime \prime} \mathrm{N} 23^{\circ} 25^{\prime} 32^{\prime \prime} \mathrm{E}, 22.09 .2011$, O.Yu. Akulov [CWU (Myc) AS 4704].

On stromata of Annulohypoxylon multiforme (Fr.) Y.M. Ju, J.D. Rogers \& H.M. Hsieh on bark of Alnus incana (L.) Moench. - Ivano-Frankivsk Region, Nadvirna District, Gorgany Nature Reserve, Gorgany forestry, along Dzhurdzhynets stream, $48^{\circ} 28^{\prime} \mathrm{N} 24^{\circ}$ $17^{\prime}$ E, 28.08.2010, V.P. Hayova [ $\left.K W 60669\right]$.

On stromata of $A$. multiforme on bark of Betula pendula Roth. - Ivano-Frankivsk Region, Nadvirna District, Gorgany Nature Reserve, beech-spruce forest with admixture of birch, quarter $14,48^{\circ} 29^{\prime} \mathrm{N} 24^{\circ} 17^{\prime} \mathrm{E}$, 30.08 .2010 , V.P. Hayova [ $K W 60671]$

General distribution. Europe: Austria, Belgium, France, Lithuania, Norway, Poland, Russia (European part), Sweden, Switzerland, Ukraine. Asia: China. 
Fig. 2. Immotthia atrograna $\lceil C W U$ Myc AS 4704]: $a$ - vertical section through ascomata, bar: $250 \mu \mathrm{m} ; b-$ surface view of ascoma, bar: 250 $\mu \mathrm{m} ; c-$ ascomatal peridium; $d-$ ascospores, bar: $13 \mu \mathrm{m}, e-$ ascus and part of hamathecium, bar: 40 $\mu \mathrm{m}$

Fig. 3. Anamorph of Immotthia atrograna, Coniothyrium parasitans [KW 60665]: $a$ - conidiogenous cells, bar: $10 \mu \mathrm{m} ; b$ - conidia, bar: $8 \mu \mathrm{m}$
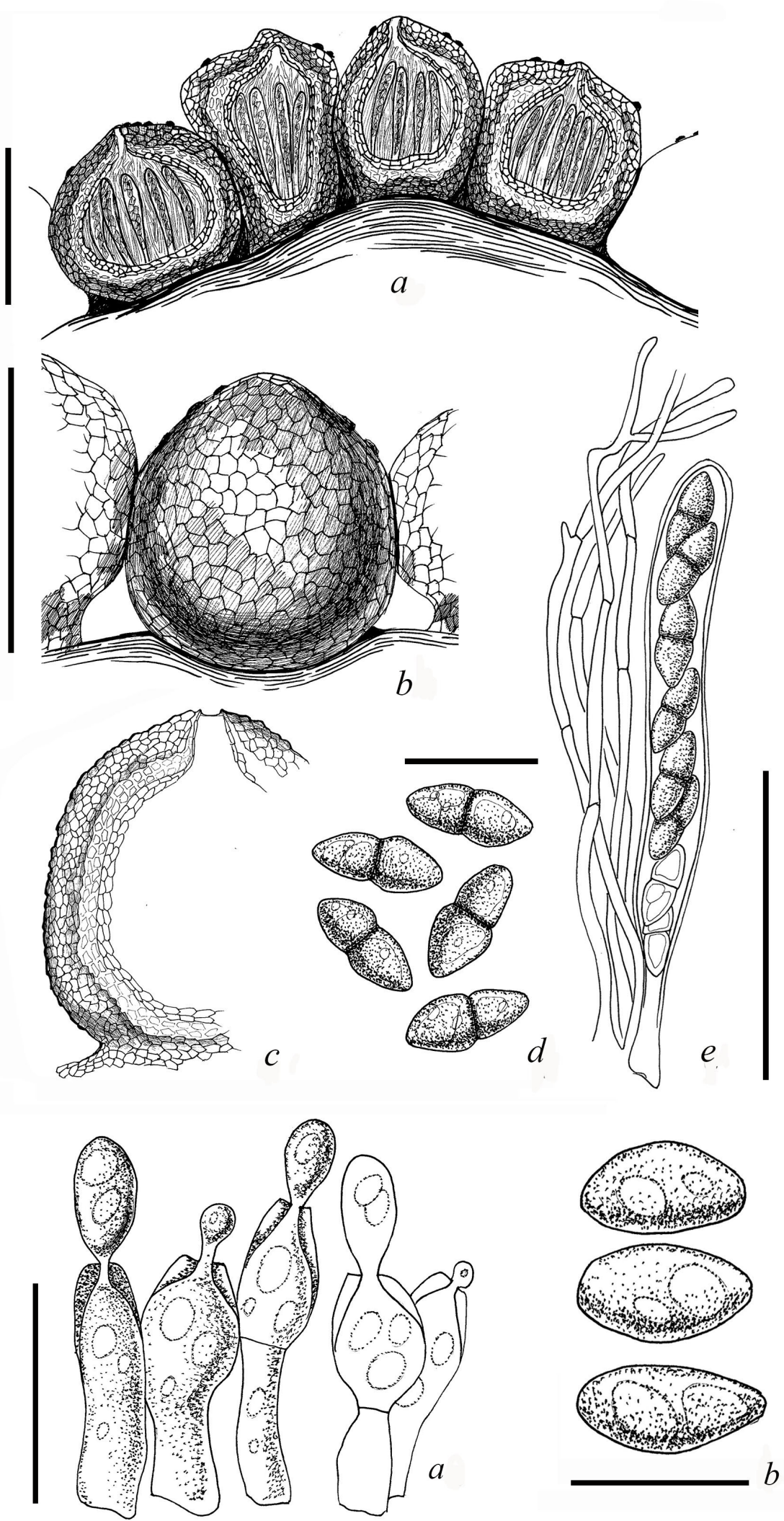
North America: USA. South America: Venezuela, Puerto-Rico.

Host specialization. Stromata of Annulohypoxylon cohaerens $^{* *}$, A. multiforme, Hypoxylon rubiginosum (Pers.) Fr., and $H$. perforatum (Schwein.) Fr., occasionally also a decayed wood of various hardwoods, particularly in humid forest habitats.

Polish mycologists A. Chlebicki and A. Skirgiełło (1995) consider Immotthia atrograna «an obligatory fungicolous saprophyte». On the contrary, W. Jaklitsch et al. (2002) are inclined to regard I. atrograna as an obligate parasite attacking host stromata in all stages of their development. In the latter case, parasitic nature of the fungus is supported by inability of ascospores to germinate on artificial media.

The anamorph of this fungus indicated here as Coniothyrium parasitans belongs to morphologically extremely variable group of coelomycetous fungi. Recent studies of cultural characteristics and DNA sequence data of the Coniothyrium-like fungi have demonstrated that their morphological features are often not suitable to delimit formerly recognisable species and genera. Based on multi-locus DNA phylogeny combined with detailed morphological analyses, several new genera were proposed; moreover, some families within the Pleosporales were redefined (Verkeley et al., 2004, 2014). In the present study, we did not observe annellidic conidiogenous cells, the most distinctive Coniothyrium character. Thus asexual morph of the reported species, due to phialidic conidiogenesis and described above conidiomatal and conidial characters, may be transferred to one of the novel genera; however, molecular phylogenetic evidence for the redisposal is required.

Morphologically very close to Immotthia atrograna is a non-fungicolous species, Coleroa pusiola (P. Karst.) Sivan., described from wood of Salix myrsinifolia Salisb. (as $S$. nigricans Smith) from Finland. This fungus was previously known as Amphisphaeria pusiola P. Karst., or Didymosphaeria pusiola (P. Karst.) Rehm. Description and illustrations of the holotype specimen of Coleroa pusiola provided by A. Sivanesan (1975) show ascospore size 9-12 × 3.5-4.5 $\mu \mathrm{m}$, while the holotype collection of Immotthia atrograna features slightly longer and wider ascospores $(13-15 \times 5-7 \mu \mathrm{m})$. M. Barr (1993) who examined numerous specimens of Immotthia atrograna, observed very wide ascospore size range in this species. She suggested that Coleroa pusiola might be another

** On stromata of Annulohypoxylon cohaerens this fungus is first reported here. species of Immotthia, with a thinner peridium, up to 25 $\mu \mathrm{m}$ wide, and slightly smaller ascospores.

Quite resembling Immotthia atrograna in general appearance and micromorphological features are species of another genus, Didymosphaeria Fuckel. They also have one-septate brown ascospores; moreover, some species are characterized by fungicolous habit, for example, Didymosphaeria eutypae Sureya, D. cocconiae Arx (= Didymosphaeria cocconiae var. major Bat. \& Peres), and D. conoidea Niessl. D. eutypae, a parasite of stromatic pyrenomycete Eutypa spp. described from France, differs in having wider ascospores $(8 \times 7.5-8$ $\mu \mathrm{m})$. D. cocconiae has significantly larger ascospores $(18-24 \times 7-8.5 \mu \mathrm{m})$. This species described as a parasite of Hysterostomella spurcaria (Berk. \& Broome) Höhn. (as Cocconia spurcaria (Berk. \& Broome) Arx) is known from the Philippines islands and Brazilia (Pirozynski, 1973). D. conoidea has almost identical in size ascospores $(9-) 10-12(-14) \times 4-5(-6) \mu \mathrm{m}$; however, it occurs mostly on members of the Leptosphaeriaceae M.E. Barr on plant litter (Shoemaker, Babcock, 1990).

A student of V.N. Karazin National University of Kharkiv, O.V. Romanchenko, is thanked for preparing line drawings for this publication.

\section{REFERENCES}

ASCOFrance, available at: http://www.ascofrance.com (accessed 12 March 2015)

Barr M.E. New taxa and combinations in the loculoascomycetes, Mycotaxon, 1987a, 29: 501-505.

Barr M.E. Prodromus to class Loculoascomycetes, Amherst: University of Massachusetts, 1987b, $168 \mathrm{pp}$.

Barr M.E. Redisposition of some taxa described by J.B. Ellis, Mycotaxon, 1993, 46: 45-76.

Barr M.E. Teichosporaceae, another family in the Pleosporales, Mycotaxon, 2002, 82: 373-389.

Chlebicki A. Some ascomycete fungi from primeval forests of north-east Poland, Acta Mycologica, 2005, 40(1): 71-94.

Chlebicki A., Skirgiełło A. Some mycogenous fungi from Poland, Acta Mycologica, 1995, 30(1): 81-93.

Dictionary of the Fungi, $10^{\text {th }}$ ed. Eds P.M. Kirk and P.F. Cannon, D.W. Minter, J.A. Stalpers, Egham, UK: CABI Bioscience; Utrecht, The Netherlands: CBS, 2011, 784 pp.

Eriksson O.E. The non-lichenized Pyrenomycetes of Sweden, Lund: SBT-forlaget, 1992, 208 pp.

Grand L.F. Pestalopezia rhododendri and an associated hyperparasite in North Carolina, J. Elisha Mitchell Sci. Soc., 1973, 89: 111-114.

Jaklitsch W., Scheuer Ch., Voglmayr H. Notes on the genus Immotthia (Pleosporales, Ascomycetes), including some type studies, Österreichische Zeitschrift für Pilzkunde, 2002, 11(14): 93-106. 
MycoBank, available at: http://www.mycobank.org (accessed 6 April 2015)

Petrak F. Mykologische Bemerkungen, Sydowia, 1957 [1958], 11(1-6): 37-353.

Pirozynski K.A. Three hyperparasites of Ascomycetes, $M y$ cologia , 1973, 65(4): 761-767.

Shoemaker R.A., Babcock C.E. Didymosphaeria conoidea Niessl. In: Fungi Canadenses, 1990, Pl. 328.

Sivanesan A. Redisposition and descriptions of some $\mathrm{Am}$ phisphaeria species and a note on Macrovalsaria, Transactions of the British Mycological Society, 1975, 65(3): 395-402.

Verkley G.J.M., da Silva M., Wicklow D.T., Crous P.W. Paraconiothyrium, a new genus to accommodate the mycoparasite Coniothyrium minitans, anamorphs of Paraphaeosphaeria, and four new species, Studies in Mycology, 2004, 50: 323-335.

Verkley G.J.M., Dukik K., Renfurm R., Göker M., Stielow J.B. Novel genera and species of coniothyriumlike fungi in Montagnulaceae (Ascomycota), Persoonia, 2014, 32: 25-51.

Wang, Y.Z., Aptroot A., Hyde K.D. Revision of the ascomycete genus Amphisphaeria, Hong Kong: Fungal Diversity Press, 2004, 168 pp.

Recommended for publication

Submitted 15.10.2015

by V.P. Heluta
Акулов О.Ю. ${ }^{1}$, Гайова В.П. ${ }^{2}$ Immotthia atrograna - новий для території України вид мікофільних грибів із Карпат. Укр. ботан. журн. - 2016. - 73(1): 84-89.

${ }^{1}$ Харківський національный університет імені В.Н. Каразіна пл. Свободи, 4, м. Харків, 61077, Україна

${ }^{2}$ Інститут ботаніки імені М.Г. Холодного НАН України вул. Терещенківська, 2, м. Київ, 01004, Україна

Повідомляється про перші знахідки в Україні мікофільного гриба Immotthia atrograna (Cooke \& Ellis) M.E. Barr. Усі зразки зібрані в старовікових лісах під час мікологічних обстежень на природоохоронних територіях Українських Карпат. Гриб знайдений на двох видах грибів Annulohypoxylon cohaerens (Pers.) Y.M. Ju, J.D. Rogers \& H.M. Hsieh i A. multiforme (Fr.) Y.M. Ju, J.D. Rogers \& H.M. Hsieh. Наведено діагностичний опис, номенклатурні дані, географічне поширення та оригінальні ілюстрації, а також вміщено стислі відомості для порівняння з морфологічно подібними мікофільними грибами.

Ключові слова: Pleosporales, Immotthia, Hypoxylon, Coniothyrium parasitans, мікопаразити, Українські Карпати.

Акулов А.Ю. ${ }^{1}$, Гаевая В.П. ${ }^{2}$ Immotthia atrograna - новый для территории Украины вид микофильных грибов из Карпат. - Укр. ботан. журн. - 2016. - 73(1): 84-89.

${ }^{1}$ Харьковский национальный университет имени В.Н. Каразина пл. Свободы, 4, г. Харьков, 61077, Украина

${ }^{2}$ Институт ботаники имени Н.Г. Холодного НАН Украины

ул. Терещенковская, 2, г. Киев, 01004, Украина

Сообщается о первых находках в Украине микофильного гриба Immotthia atrograna (Cooke \& Ellis) M.E. Barr. Bce образцы собраны в старовозрастных лесах во время микологических обследований на природоохранных территориях Украинских Карпат. Гриб обнаружен на двух видах грибов - Annulohypoxylon cohaerens (Pers.) Y.M. Ju, J.D. Rogers \& H.M. Hsieh и A. multiforme (Fr.) Y.M. Ju, J.D. Rogers \& H.M. Hsieh. Приведены диагностическое описание, номенклатурные данные, географическое распространение и оригинальные иллюстрации, краткие сведения для сравнения с морфологически сходными микофильными грибами.

Ключевые слова: Pleosporales, Immotthia, Hypoxylon, Coniothyrium parasitans, микопаразиты, Украинские Карпаты. 